\title{
Hyperbaric Oxygen Stimulates the Proliferation and Differentiation of Raw264.7 Cells
}

\author{
Tomotaka Sugi, Masanori Sasaki, Takahiro Yamashiro, Takaoki Tsuneyoshi, \\ Arioka Masaki, Akihiko Matsumoto, Kumamaru Wataru, Nakano Hiroyuki, \\ Mori Yoshihide \\ Section of Oral and Maxillofacial Surgery, Division of Maxillofacial Diagnostic and Surgical Sciences, Faculty of \\ Dental Science, Kyushu University, Japan \\ Email: sugizoo@dent.kyushu-u.ac.jp
}

Received 22 November 2015; accepted 22 December 2015; published 25 December 2015

Copyright (C) 2015 by authors and Scientific Research Publishing Inc.

This work is licensed under the Creative Commons Attribution International License (CC BY).

http://creativecommons.org/licenses/by/4.0/

(c) (i) Open Access

\begin{abstract}
Background: Hyperbaric Oxygen (HBO) Therapy improves the outcome of various types of sugery, such as postoperative bone grafts, fixation of jaw fractures, and osteoplasty of jaw deformities. Therefore, it is important to determine the effects of $\mathrm{HBO}$ on bone regeneration. The purpose of this study was to clarify the influence of a hyperbaric oxygen environment on bone regeneration at the osteoclastogenic cytokines level. Sample \& Methods: RAW264.7 cells were stimulated under the various conditions by using a hyperbaric oxygen chamber. We evaluated the ability of the RAW264.7 macrophages to proliferate, differentiate and produce various osteoclastogenic cytokines. Results: A hyperbaric oxygen (HBO) environment and high concentration oxygen (HCO) environment increase cellular proliferation in a time-dependent manner. On the other hand, a HCO environment and a hyperbaric with room air (HBA) environment enhanced the differentiation of RAW264.7 cells. In addition, NFATc1 and c-Fos were increased by both the HBA environment and HCO environment. However, the effects of HBA and HCO environments were in contrast with each other with regard to RANK, TNF- $\alpha$, C-FMS and TRAP. Conclusions: It was suggested that a HBO environment influenced the bone regeneration by altering osteoclastogenic cytokines level, and that a HCO environment and HBA environment acted independently on the proliferation and differentiation of macrophages and the secretion of osteoclastogenic cytokines, and that they acted in concert in a hyperbaric oxygen environment to induce conditions favoring regeneration.
\end{abstract}

\section{Keywords}

Hyperbaric Oxygen Therapy, Bone Regeneration, Osteoclast, RAW264.7 


\section{Introduction}

Hyperbaric Oxygen (HBO) Therapy improves the outcome of various types of surgery, such as the repair of bone fractures [1]-[3], osteoplasty of jaw deformities, the treatment of osteoradionecrosis [4]-[6] and distraction osteogenesis [7] [8], as well as postoperative bone grafting [1] [9] and the use of dental implants [10]. The reason was generally assumed that HBO stimulates the growth of blood vessels, thus resulting in an increased blood supply and enhanced bone formation [11]. This is partly because HBO is believed to generate reactive oxygen species (ROS) and reactive nitrogen species (RNS) that affect signaling processes critical to wound healing.

In recent years, the use of bone augmentation and sinus floor augmentation for dental implant treatment has increased. Therefore, it is important to determine the effect of $\mathrm{HBO}$ on bone regeneration. Although animal studies have shown that HBO can be used to treat delayed fracture healing [12]-[14] or an established nonunion of a bony fracture [12] [15] [16], the clinical application of HBO is still subject to debate [12] [17]-[19] due to the lack of in vitro studies, for example, to demonstrate its effect on osteoclast activity.

Osteoclasts are a member of the monocyte/macrophage lineage and are formed by multiple cellular fusions from their mononuclear precursors. They play an important role in bone metabolism by regulating bone resorption. Receptor activator of nuclear factor $-\kappa \mathrm{B}$ ligand (RANKL) induces the differentiation of osteoclasts from myeloid precursors at various intermediate stages, as well as from well differentiated tissue macrophages, such as alveolar macrophages [20]. Osteoclasts attach to the surface of bone and secrete protons into an extracellular compartment between the osteoclast and bone surface. The osteoclast proton pump is essential for bone mineral solubilization and digestion of organic bone matrix by acid proteases [21]. There are two crucial steps in osteoclast formation: commitment of progenitor cells to osteoclast precursor cells, and fusion of mononuclear cells to form TRAP-positive, multinucleated osteoclasts. The activation of the receptor for RANKL (RANK) is a key step in the differentiation of mature osteoclasts during the late stage of this process [22]-[24]. RANKL is a member of the tumor necrosis factor (TNF) superfamily, and acts as a key regulator of osteoclasts. It induces transcription factors such as NF- $\kappa$ B, c-Fos, and nuclear factor of activated T cells (NFAT) cl, which play an essential role in osteoclast differentiation, fusion, and function [25]-[27]. The regulation of irreversible cell lineage commitment depends on a delicate balance between positive and negative regulators, which comprise a sophisticated network of transcription factors. Robust osteoclast-specific induction of NFATc1 is achieved through an autoamplification mechanism, in which NFATc1 is constantly activated by calcium signaling, while the negative regulators of NFATc1 are suppressed. However, it has been unclear how such negative regulators are repressed during osteoclastogenesis. NF- $\kappa$ B induces the initial induction of NFATc1, the expression of which is autoamplified by NFATc1 binding to its own promoter in cooperation with c-Fos [28]. This autoamplification mechanism enables the strong induction of NFATc1 specific to osteoclasts [26].

RAW264.7 cells were employed as a model system for developing osteoclasts in this study. Upon treatment with RANKL, these cells stain positively for TRAP within 1 day and start to fuse after 4 to 5 days to generate multinucleated cells, a hallmark of fully differentiated osteoclasts [29]. RAW264.7 cells have served as a model for osteoclasts in multiple contemporary studies dealing with osteoclast physiology or the RANK/RANKL/OPG interaction [30]-[32]. Although RAW264.7 cells are of murine origin, which might be considered a drawback of the study design, they represent a well-established and reproducible model, and the cells respond robustly to human RANKL, which legitimates the experimental approach of co-culturing human PDL cells with murine monocytes/macrophages [33]. The characterization of osteoclasts by the TRAP assay is a well-accepted method to characterize these cells, and was also adopted in recent reviews on osteoclast biology [34]. The purpose of this study was to clarify the influence of a hyperbaric oxygen environment on bone regeneration at the cellular level. The information obtained from such studies should therefore advance the overall understanding of osteoclastogenic cytokines and the mechanism of bone regeneration under HBO, thereby potentially leading to novel therapeutic approaches to bone diseases.

\section{Materials and Methods}

\subsection{Reagents}

Recombinant human soluble RANKL (sRANKL) was purchased from Chemicon International (Temecula, CA, USA). Mouse monoclonal antibodies against NFATc1, rabbit polyclonal antibodies against c-FOS, RANK, and 
goat polyclonal antibodies against $\beta$-actin were purchased from Santa Cruz Biotechnology (Santa Cruz, CA, USA).

\subsection{Cell Culture}

The mouse monocyte-macrophagic cell line, RAW264.7 cells, were obtained from Dainippon Pharmacy Co. (Osaka, Japan). RAW264.7 cells were cultured in $\alpha$-minimal essential medium ( $\alpha$-MEM, GIBCO) containing 10\% heat-inactivated fetal bovine serum (FBS; CSL, Victoria, Australia), $100 \mathrm{U} / \mathrm{ml}$ penicillin, $100 \mu \mathrm{g} / \mathrm{ml}$ streptomycin, and $1 \mathrm{mM} \mathrm{L}$-glutamine at $37^{\circ} \mathrm{C}$ in a humidified atmosphere of $5 \% \mathrm{CO}_{2}$ in air.

\subsection{Stimulation of Raw264.7 Cells}

RAW264.7 cells were treated daily for up to 7 days in a custom-made hyperbaric oxygen chamber (Figure 1). The chamber was sealed and flushed for 2 minutes with $95 \% \mathrm{O}_{2}$ and $5 \% \mathrm{CO}_{2}$, and the pressure was subsequently increased to 1.4 atmosphere absolute (ATA). The hyperbaric oxygen (HBO) treatment consisted of $95 \% \mathrm{O}_{2}$ and $5 \% \mathrm{CO}_{2} / 1.4$ ATA, hyperbaric with room air (HBA) was room air/1.4 ATA, and high concentration oxygen (HCO) was $95 \% \mathrm{O}_{2}$ and $5 \% \mathrm{CO}_{2} / 1.0$ ATA. Following various conditions were set up to search for a more effective conditions. The pressure was maintained for 20 or 60 minutes, after which the chamber was slowly depressurized over 5 minutes. RAW264.7 cells were stimulated under the various conditions for 1) 20 minutes, 2) 20 minutes $\times 3$, 3) 20 minutes $\times 7$, 4) 60 minutes, 5) 60 minutes $\times 3$, 6) 60 minutes $\times 7$. After 8 days, both cell proliferation and differentiation were analyzed.

\subsection{Effect on Proliferation}

We analyzed the proliferation of the cells by the MTS assay using a CellTiter $96^{\circledR}$ AQueous One Solution Cell Proliferation Assay kit (Promega KK, USA) according to the manufacturer's instructions.

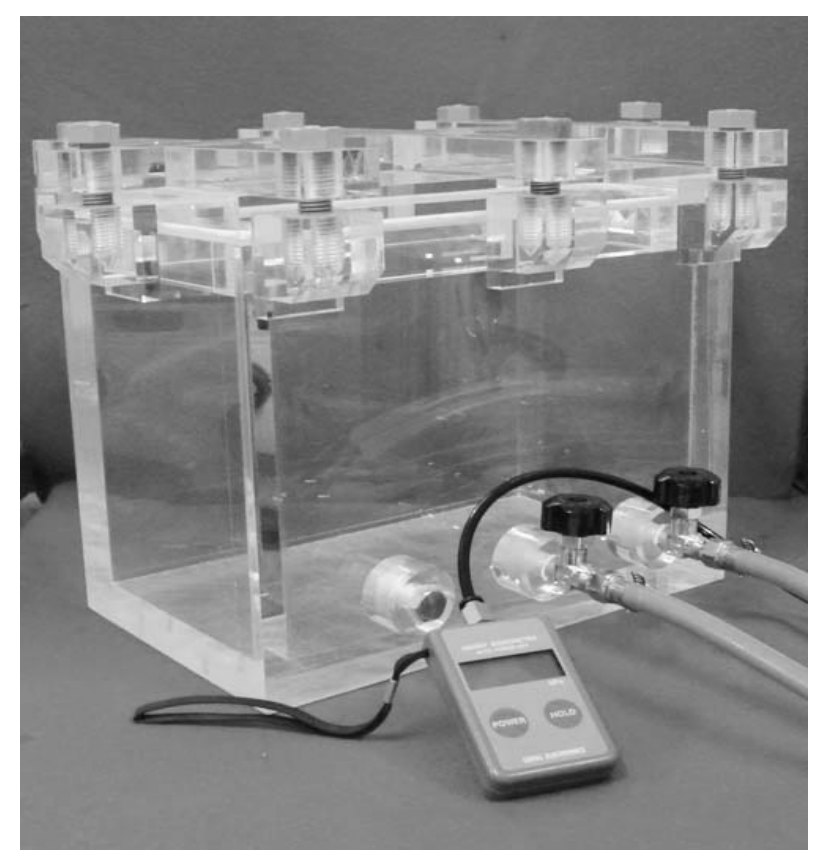

Figure 1. The custom-made hyperbaric oxygen chamber. The chamber was sealed and flushed for 2 minutes with $95 \% \mathrm{O}_{2}$ and $5 \% \mathrm{CO}_{2}$, then the pressure was subsequently increased to 1.4 atmosphere absolute (ATA). HBO treatment consisted of $95 \% \mathrm{O}_{2}$ and $5 \% \mathrm{CO}_{2} / 1.4$ ATA, HBA of room air/1.4 ATA, and HCO treatment consisted of $95 \% \mathrm{O}_{2}$ and $5 \% \mathrm{CO}_{2} / 1.0$ ATA. The pressure was maintained for 20 or 60 minutes, after which the chamber was slowly depressurized over 5 minutes. 
RAW264.7 cells were seeded at $3.0 \times 10^{3}$ cells in 96-well plates and cultured in $\alpha$-MEM at $37^{\circ} \mathrm{C}$ in a humidified atmosphere with $5 \% \mathrm{CO}_{2}$. After one day, the RAW264.7 cells were stimulated according to our protocol.

\subsection{Effect on Differentiation}

We analyzed the ability of the cells to differentiate by the Tartrate-resistant acid phosphatase (TRAP) activity assay. RAW264.7 cells were seeded at $3.0 \times 10^{3}$ cells in 96-well plates and cultured in $\alpha$-MEM supplemented with RANKL $(100 \mathrm{ng} / \mathrm{ml})$ at $37^{\circ} \mathrm{C}$ in a humidified atmosphere with $5 \% \mathrm{CO}_{2}$. TRAP activity was examined with a TRAP staining kit (Hokudo, Hokkaido, Japan) according to the manufacturer's instructions. After stimulation, $30 \mu \mathrm{l}$ of cell culture media were incubated with $170 \mu \mathrm{l}$ of staining solution in the kit for 3 hours. Thereafter, the absorption of the reaction mixture was measured at $550 \mathrm{~nm}$ with a microplate reader (Colona Electric, Ibaragi, Japan).

\subsection{Real-Time PCR}

RAW264.7 cells were seeded at $4.5 \times 10^{5}$ cells in $10 \mathrm{~cm}$ plates and cultured in $\alpha$-MEM supplemented with RANKL $(100 \mathrm{ng} / \mathrm{ml})$ at $37^{\circ} \mathrm{C}$ in a humidified atmosphere with $5 \% \mathrm{CO}_{2}$ and stimulated according to our protocol.

Optimized oligonucleotide primers were purchased from NIHON GENE RESEARCH LABORATORIES (Sendai, Japan). Real-time PCR was performed on a light-cycler (Roche, Tokyo, Japan). The PCR cycling conditions were $10 \mathrm{~min}$ at $95^{\circ} \mathrm{C}$ for 1 cycle followed by 45 cycles each of $95^{\circ} \mathrm{C}$ for $30 \mathrm{~s}, 65^{\circ} \mathrm{C}$ for $30 \mathrm{~s}$, and $72^{\circ} \mathrm{C}$ for $60 \mathrm{~s}$. The following oligonucleotides [35] [36] were used: $\beta$-actin sense 5'-AGCACCATGAAGATCAAG-3', anti-sense 5'-GTAAAACGCAGCTCAGTAA-3'; NFATc1 sense 5'-GGGAGATGGAAGCAAAGACT-3', antisense 5'-AAGGTACGTGAAACGCTGGT-3'; c-Fos sense 5'-CTGTCCGTCTCTAGTGCCAACTT-3', antisense 5'-ATCTGTC TCCGCTTGGAGCGTAT-3'; TRAP sense 5'-ACGTGCCCAACTGCTACA-3', anti-sense 5'-GGGGTCATCAACGAGTCCT-3'; RANK sense 5'-CATCATCTTCGGCGTTTAC-3', anti-sense 5'GATACCTT-ACACACTTCTTGC-3'; TNF- $\alpha$ sense 5'-CTCTTCTCATTCCTGCTTG-3', anti-sense 5'GTCTGGGCCATAGAACTGAT-3'; C-FMS sense 5'-ACAAGGCAGGCTGGAATA-3', anti-sense 5'CCAGAGACGTCACAGAACAG-3'.

\subsection{Western Blot Analysis}

RAW264.7 cells were seeded at $4.5 \times 10^{5}$ cells in $10 \mathrm{~cm}$ plates and cultured in $\alpha$-MEM supplemented with RANKL $(100 \mathrm{ng} / \mathrm{ml})$ at $37^{\circ} \mathrm{C}$ in a humidified atmosphere with $5 \% \mathrm{CO}_{2}$ and stimulated according to our protocol.

Samples were lysed in lysis buffer, and the aliquots of the samples were run on 10\% SDS-polyacrylamide gels, and transferred onto nitrocellulose membrane (Bio-Rad, Hercules, CA, USA) at $50 \mathrm{mV}$ for 10 hours. The nitrocellulose membrane was incubated with 5\% bovine serum albumin in TBST for 1 hour to eliminate nonspecific binding, and incubated with a 1:200 dilution of polyclonal antibody against NFATc1, c-Fos or RANK. Protein bands were visualized using HRP-conjugated secondary antibodies and the Enhanced Chemiluminescence Reagent (Amersham Pharmacia Biotech, Piscataway, NJ, USA). The bands were scanned by computerassisted densitometry (ChemiDoc XRS-J, Bio-Rad) and acquired using the Quantity One software package (Bio-Rad).

\subsection{Statistical Analysis}

All quantitative results are expressed as the means \pm SD. Statistical differences between experimental groups were analyzed by Student's $t$-test. Values of $p<0.05$ were considered to be statistically significant.

\section{Results}

\subsection{Proliferation of Raw264.7 Cells}

We examined the effects of HBO on RAW264.7 cell proliferation using the MTS assay. As shown in Figure 2(a), at hyperbaric oxygen (HBO), the proliferation was significantly higher in the cells incubated for 20 minutes $\times 7,60$ minutes, 60 minutes $\times 3$, and 60 minutes $\times 7$ compared with the untreated controls. In the cells in- 
cubated for 20 minutes or for 20 minutes $\times 3$, no significant difference was noted between the treated and the untreated controls. Under hyperbaric with room air (HBA) conditions, the proliferation was significantly lower for the cells treated for 20 minutes $\times 3$, but under the other conditions, no differences in proliferation were noted between the treated cells and untreated controls (Figure 2(b)). After incubation under a high concentration of oxygen (HCO), the proliferation was significantly higher for the cells incubated for 20 minutes $\times 3$, and 20 minutes $\times 7$. The other conditions did not induce any significant change in proliferation compared with control cultures (Figure 2(c)).

\subsection{Differentiation of Raw264.7 Cells}

We next examined the effects of stimulation on RAW264.7 cell differentiation by the TRAP assay. As shown in Figure 3(a), under HBO, there was significantly more differentiation in the cells incubated for 20 minutes, while it was lower for those incubated for 60 minutes, 60 minutes $\times 3$, and 60 minutes $\times 7$ compared with the untreated controls. For the cells incubated for 20 minutes $\times 3$, and 20 minutes $\times 7$, no significant difference in differentiation was noted between the treated cells and the untreated controls. In the cells cultured under HBA, the differentiation was significantly higher for cells incubated for 20 minutes compared with the untreated controls. No difference in the differentiation was noted between the untreated cells and those incubated under the

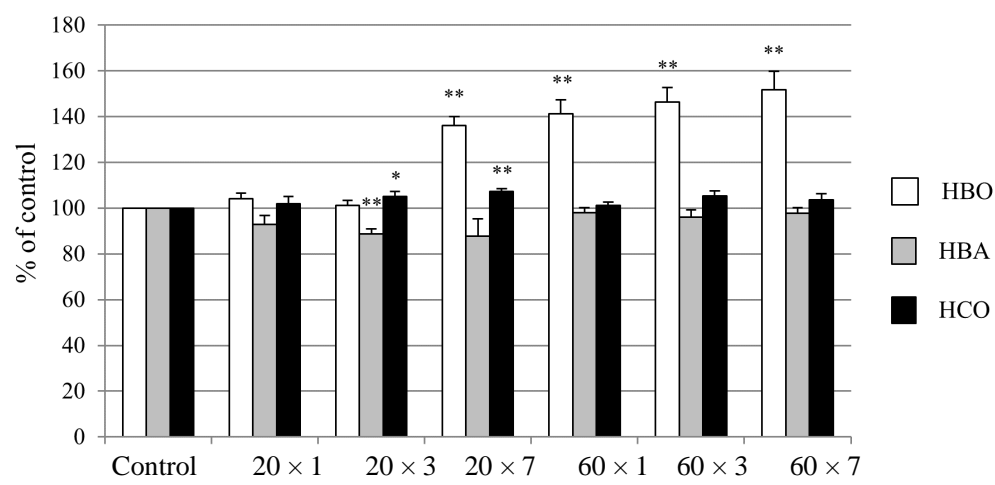

Figure 2. The effects of stimulation on the proliferation, as determined by the MTS assay. RAW264.7 cells were cultured in 10\% FCS for $24 \mathrm{hr}$ and subsequently treated with HBO, HBA or HCO for the indicated times (20 min or $60 \mathrm{~min}$, once, three times or seven times). Proliferation was analyzed by the MTS assay. ** Significantly different from the control $(p<0.01)$. * Significantly different from the control $(p<0.05)$.

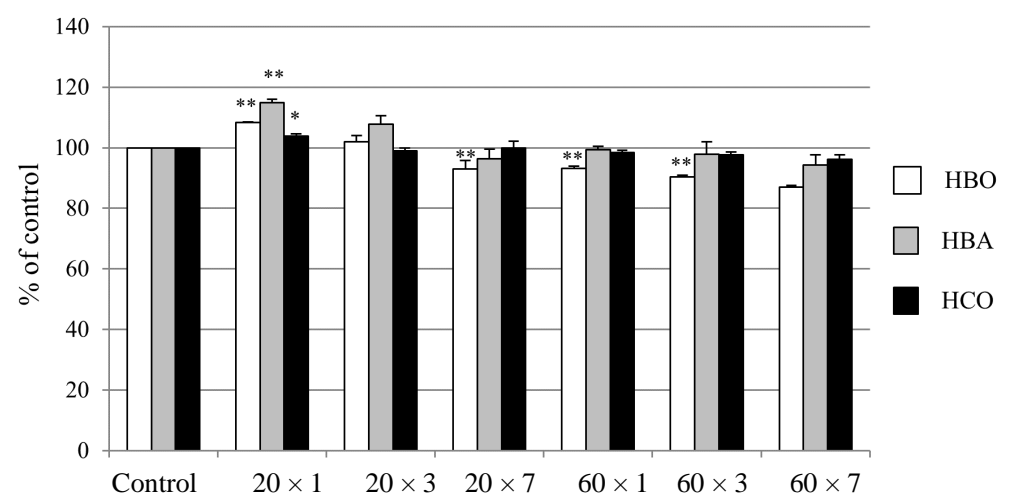

Figure 3. The effects of stimulation on differentiation determined by the TRAP assay. RAW264.7 cells were cultured in 10\% FCS and treated with $100 \mathrm{ng} / \mathrm{ml}$ RANKL for 8 days, then were treated with HBO, HBA or HCO. Differentiation was analyzed by the TRAP assay. ${ }^{* *}$ Significantly different from the control $(\mathrm{p}<0.01)$. * Significantly different from the control $(\mathrm{p}<$ 0.05 ). 
other conditions (Figure 3(b)). The differentiation was significantly higher for cells incubated under HCO for 20 minutes compared with the untreated controls. However, no significant difference in the differentiation was noted between the cells treated for other periods of time and the untreated controls (Figure 3(c)).

\subsection{Expression of mRNA}

To investigate whether the stimulation of RAW264.7 cell differentiation alters the expression of osteoclastogenic cytokines, we examined the expression of NFATcl, c-Fos, TRAP, RANK, TNF- $\alpha$, and C-FMS. As shown in Figure 4, NFATc1 increased after all forms of stimulation. While c-Fos was observed to decrease in cells incubated for 20 minutes, 20 minutes $\times 3$, and 60 minutes under HBO, HBO increased cellular differentiation in a time-dependent manner in the cells incubated for 60 minutes. Under HBA and HCO increased too. RANK and C-FMS were increased by HBO, HCO, and decreased by HBA. On the other hand, TNF- $\alpha$ increased by HBO and HBA, and decreased by HCO. TRAP was increased by HBA, and decreased by HCO. TRAP also generally decreased by HBO.

a) $\mathrm{HBO}$

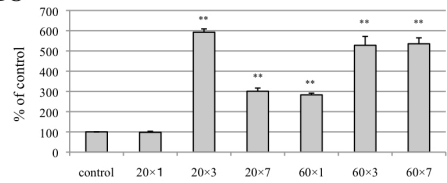

b) $\mathrm{HBA}$

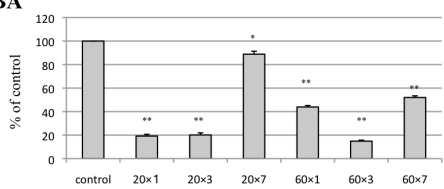

c) $\mathrm{HCO}$

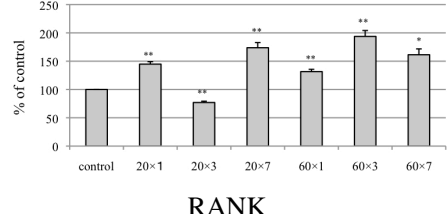

a) $\mathrm{HBO}$

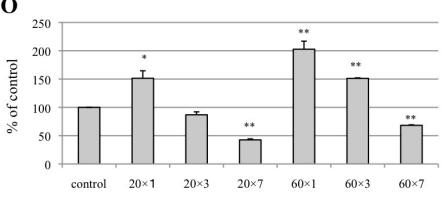

b) $\mathrm{HBA}$

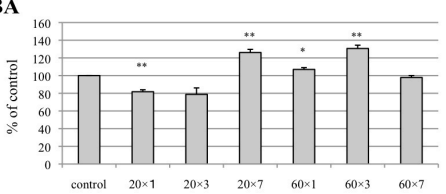

c) $\mathrm{HCO}$

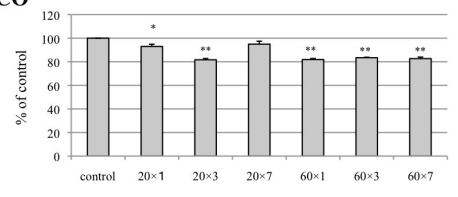

RANK a) $\mathrm{HBO}$

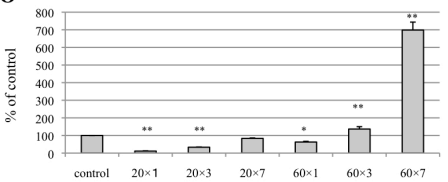

b) HBA

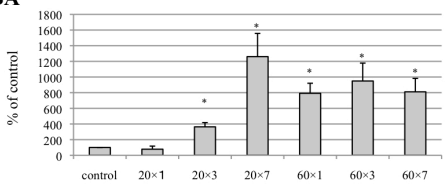

c) $\mathrm{HCO}$

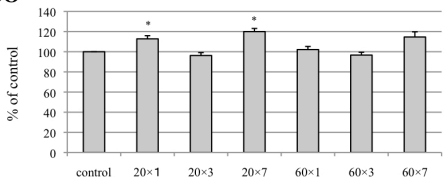

c-Fos

a) $\mathrm{HBO}$

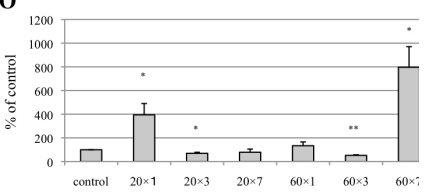

b) $\mathrm{HBA}$

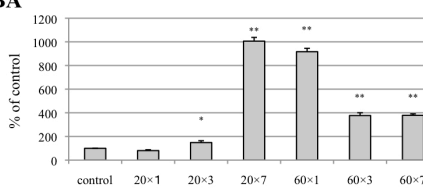

c) $\mathrm{HCO}$

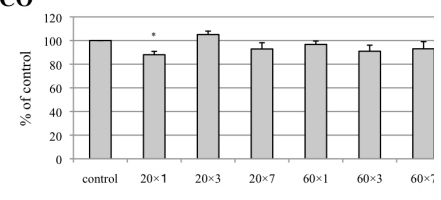

c-Fos a) $\mathrm{HBO}$

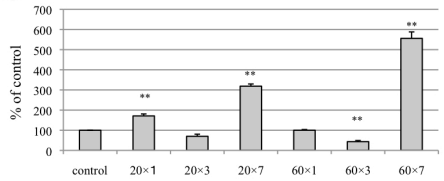

b) $\mathrm{HBA}$

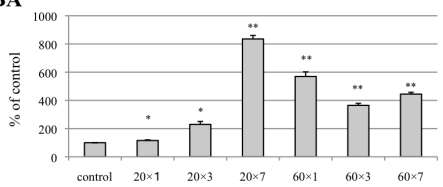

c) $\mathrm{HCO}$

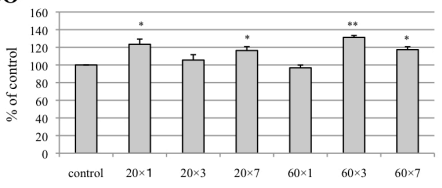

NFATc1

a) $\mathrm{HBO}$

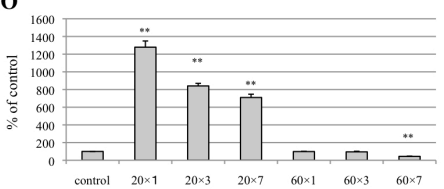

b) $\mathrm{HBA}$

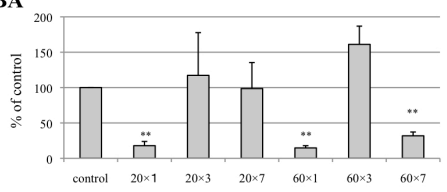

c) $\mathrm{HCO}$

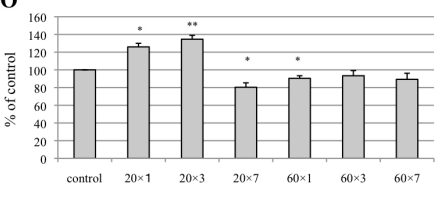

NFATc1

Figure 4. The effects of stimulation on the expression of osteoclastogenic cytokines in RANKL-treated RAW264.7 cells. RAW264.7 cells were treated with $100 \mathrm{ng} / \mathrm{ml}$ RANKL for 8 days and subsequently treated with (a) HBO, (b) HBA or (c) HCO. The expression of NFATcl, c-Fos, TRAP, RANK, TNF-a, and C-FMS mRNA was measured by real-time PCR. The b-actin mRNA level was used as an internal quantity control. ${ }^{* *}$ Significantly different from the control $(\mathrm{p}<0.01)$. ${ }^{*}$ Significantly different from the control $(\mathrm{p}<$ 0.05). 


\subsection{Western Blot Analysis}

The Western blotting analyses were performed to confirm whether stimulation affects c-Fos and NFATcl protein expression. We observed that the bands of c-Fos were detected in the range of 42- to 50-kDa and the bands of NFATcl were detected in the range of 83- to 119-kDa after each stimulation (Figure 5). Consistent with the marked increase in c-Fos mRNA, the c-Fos protein level was substantially increased in RAW264.7 cell-derived osteoclasts. However for NFATcl, despite the marked increase in the NFATcl mRNA level, the NFATcl protein level was decreased in RAW264.7 cell-derived osteoclasts.

\section{Discussion}

The effects of HBO on a variety of cell types have been reported previously. For example, to evaluate the potential role of HBO in skin wound healing, its effects on human dermal fibroblasts were investigated, and a stimulatory effect of HBO was reported [37] [38]. Rat hepatocytes have also been used to study the effects of HBO treatment on primary liver nonfunction [39], and benign and malignant mammary epithelial cells have been used to elucidate the inhibitory role of HBO on tumor growth [40].

A large number of studies have shown enhanced osteogenic activity as a result of HBO treatment. For example, accelerated levels of bone morphogenic proteins [41], earlier union of autologous bone grafts [9], and improved bone formation in titanium implants [42] were observed in vivo after exposure to HBO. This requirement for oxygen during healing is the rationale underlying HBO therapy, and it is generally assumed that HBO stimulates the growth of blood vessels, resulting in an increased blood supply, and as a result, enhanced bone formation [43]. It was demonstrated that after bone grafting, the formation of new bone is closely associated with the rate of vascularization [44]. In the posterolateral fusion area, the major blood supply for vascularization of the bone graft was from the upper and lower transverse processes [11]. After dissection, the healing environment between the transverse processes is relatively hypovascular. This hypovascular environment results in cell apoptosis, which ultimately affects the bone-forming ability of the cells. HBO is known to accelerate the

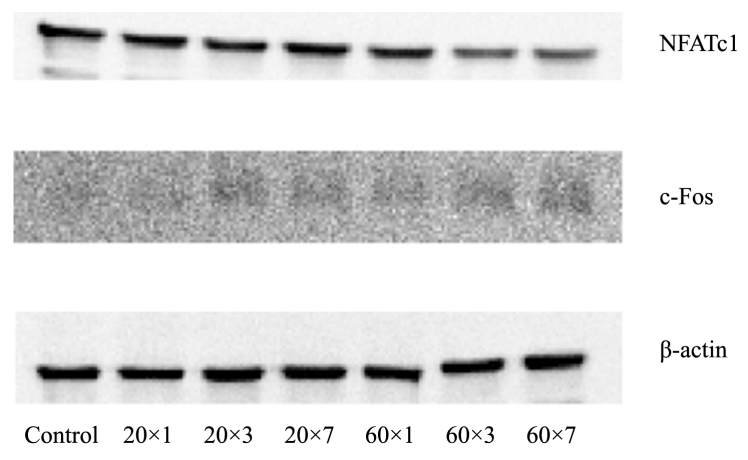

(a)
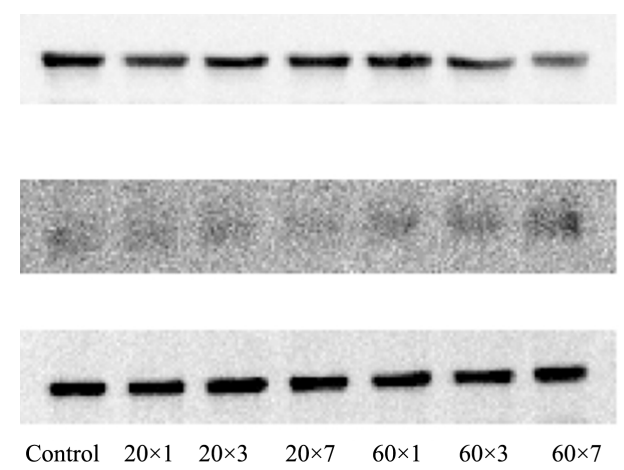

(b)
NFATc1
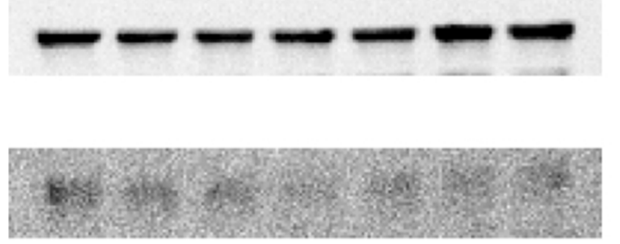

$\beta$-actin

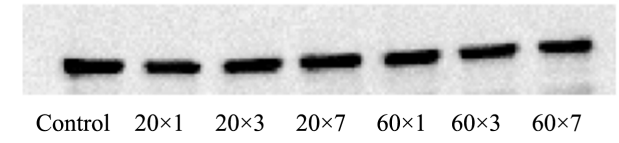

(c)

Figure 5. The effects of stimulation on the expression of c-Fos and NFATc1 protein in RANKL-treated RAW264.7 cells. RAW264.7 cells were treated with $100 \mathrm{ng} / \mathrm{ml}$ RANKL for 8 days and subsequently treated with (a) HBO, (b) HBA or (c) HCO. The expression of c-Fos and NFATc1 proteins were measured by an immunoblot analysis. 
development of new blood vessels in hypovascular tissue, which increases the vascularization in the affected area and enhances bone healing. To understand the cellular mechanisms of the observed therapeutic effects of HBO on fracture healing, our study investigated the effects of HBO on the proliferation and differentiation of RAW264.7 cells in vitro using a custom-made hyperbaric oxygen chamber.

Historically, the beneficial effects of HBO have been attributed to the establishment of a favorable oxygen gradients [45] [46]. Recent research has revealed that HBO also generates reactive oxygen species (ROS) and reactive nitrogen species (RNS) that affect signaling processes critical to wound healing [47]-[54] and have shown that HBO-derived ROS and RNS induce stem cell mobilization [50] [55] [56], vasculogenesis [51] [52] [57] [58], mitochondrial biogenesis [53], and preconditioning [59]-[62]. Because ROS and RNS are the basis for HBO's effects on signaling, its clinical consequences in any therapeutic situation will be dose-, tissue-, and time-specific. HBO increases the local concentrations of ROS and RNS [63] by providing a substrate for nitric oxide synthase, as well as by the generation of superoxide. ROS and RNS influence osetoclast differentiation and activity, and regulate other critical aspects of bone metabolism. Endothelial nitric oxide synthase is an enzyme expressed extensively in osteoclasts and osteoblasts, their marrow precursors, and in their descendents [64]. Nitric oxide is constitutively synthesized by both osteoclasts and osteoblasts, and it has contrasting biphasic effects on bone resorption, stimulating turnover at lower signaling levels and inhibiting turnover at higher, proinflammatory, concentrations [57]. ROS stimulate the expression of RANKL [65], changing the RANKL/ osteoprotegerin ratio and favoring osteoclast differentiation in animal models [66].

In the present study, we drew a comparison between a hyperbaric environment (HBA) and a high concentration oxygen environment (HCO). Our results showed that the HCO environment increased cellular proliferation in a time-dependent manner. However, when an HBA environment was used to stimulate the RAW264.7 cells, their proliferation was decreased compared with control cultures. In addition, while the effect was dependent on the duration of stimulation, both the HBA and HCO environment enhanced the differentiation of RAW264.7 cells.

These data suggest that the HCO environment enhances proliferation. However, both an HBA and HCO environment are needed to enhance cell differentiation. In addition, the TRAP activity showed that the effect of each type of stimulation was time-dependent. It was presumed that when stimulation was performed many times, both differentiation and bone resorption were inhibited. We found intriguing evidence to support the idea that the HBA and HCO environment act independently of each other on the proliferation and differentiation of RAW264.7 cells, and that they act in concert under HBO. Finally, we observed that the expression of osteoclastogenic cytokines, NFATc1 and c-Fos, increased due to both an HBA and HCO environment. This suggests that both a HBA and HCO environment enhanced the differentiation of RAW264.7 cells via increased cytokine expression. However, the effects of HBA and HCO environments were in opposition to each other in terms of RANK, TNF- $\alpha$, C-FMS and TRAP.

RAW264.7 cells were employed as a model system for developing osteoclasts in this study. Numerous researches have employed RAW264.7 cells as a single- or mono-culture. However, it is also true that this monoculture system cannot evaluate interactions of bone regeneration under HBO. Co-culture compositions of two different cell type of bone like osteoclast and osteoblast, must be established in order to evaluate cell-cell interactions of a hyperbaric oxygen environment on bone regeneration. Additionally, in this study, the pressure was subsequently increased to 1.4 ATA and was maintained for 20 or 60 minutes. Extermely important agenda is to evaluate the effect of HBO, if RAW264.7 cells are stimulated under 2.0 ATA or the various amount of time.

\section{Conclusion}

We hypothesized that HBO can stimulate bone turnover through its effects on the chemical mediators of osteoclast activation. Our results were in agreement with this hypothesis, but the more intriguing fact is that the HBA and HCO environments acted independently of each other with regard to cell proliferation and differentiation, as well as the production of osteoclastogenic cytokines, while acting together under a $\mathrm{HBO}$ environment.

\section{References}

[1] Kerwin, S.C., Lewis, D.D., Elkins, A.D., Oliver, J.L., Hosgood, G., Pechman Jr., R.D., Dial, S.L. and Strain, G.M. (2000) Effect of Hyperbaric Oxygen Treatment on Incorporation of an Autogenouscancellous Bone Graft in a Nonunion Diaphysealulnar Defect in Cats. American Journal of Veterinary Research, 61, 691-698. 
http://dx.doi.org/10.2460/ajvr.2000.61.691

[2] Wray, J.B. and Rogers, L.S. (1968) Effect of Hyperbaric Oxygenation upon Fracture Healing in the Rat. Journal of Surgical Research, 8, 373-378. http://dx.doi.org/10.1016/0022-4804(68)90050-4

[3] Yablon, I.G. and Cruess, R.L. (1968) The Effect of Hyperbaric Oxygen on Fracture Healing in Rats. Journal of Trauma, 8, 186-202. http://dx.doi.org/10.1097/00005373-196803000-00007

[4] Lentrodt, S. and Lentrodt, J. (2006) Effects of Hyperbaric Oxygen Therapy (HBO) during Treatment of Infected Free Bone Transplants. A Case Report. Mund Kiefer Gesichtschir, 10, 263-268.

http://dx.doi.org/10.1007/s10006-006-0006-8

[5] Donovan, D.J., Huynh, T.V., Purdom, E.B., Johnson, R.E. and Sniezek, J.C. (2005) Osteoradionecrosis of the Cervical Spine Resulting from Radiotherapy for Primary Head and Neck Malignancies: Operative and Nonoperative Management. Case Report. Journal of Neurosurgery: Spine, 3, 159-164. http://dx.doi.org/10.3171/spi.2005.3.2.0159

[6] David, L.A., Sandor, G.K., Evans, A.W. and Brown, D.H. (2001) Hyperbaric Oxygen Therapy and Mandibularosteoradionecrosis: A Retrospective Study and Analysis of Treatment Outcomes. Journal of the Canadian Dental Association, 67, 384.

[7] Clark, C.L., Strider, J., Hall, C., Ferguson, H.W., Armstrong, K.L., Runner, R.R. and Baur, D.A. (2006) Distraction Osteogenesis in Irradiated Rabbit Mandibles with Adjunctive Hyperbaric Oxygen Therapy. Journal of Oral and Maxillofacial Surgery, 64, 589-593. http://dx.doi.org/10.1016/j.joms.2005.12.027

[8] Wang, I.C., Yuan, L.J., Tu, Y.K., Lin, S.S., Wang, C.R., Tai, C.L. and Wang, K.C. (2005) Early Administration of Hyperbaric Oxygen Therapy in Distraction Osteogenesis-A Quantitative Study in New Zealand Rabbits. Journal of Trauma, 58, 1230-1235. http://dx.doi.org/10.1097/01.TA.0000169872.38849.B0

[9] Sawai, T., Niimi, A., Takahashi, H. and Ueda, M. (1996) Histologic Study of the Effect of Hyperbaric Oxygen Therapy on Autogenous Free Bone Grafts. Journal of Oral and Maxillofacial Surgery, 54, 975-981. http://dx.doi.org/10.1016/S0278-2391(96)90396-1

[10] Granstrom, G., Tjellstrom, A. and Branemark, P.I. (1999) Osseointegrated Implants in Irradiated Bone: A Case-Controlled Study Using Adjunctive Hyperbaric Oxygen Therapy. Journal of Oral and Maxillofacial Surgery, 57, 493-499. http://dx.doi.org/10.1016/S0278-2391(99)90059-9

[11] Yeh, W.L., Lin, S.S., Yuan, L.J., Lee, K.F., Lee, M.Y. and Ueng, S.W. (2007) Effects of Hyperbaric Oxygen Treatment on Tendon Graft and Tendon-Bone Integration in Bone Tunnel: Biochemical and Histological Analysis in Rabbits. Journal of Orthopaedic Research, 25, 636-645. http://dx.doi.org/10.1002/jor.20360

[12] Bennett, M.H., Stanford, R. and Turner, R. (2005) Hyperbaric Oxygen Therapy for Promoting Fracture Healing and Treating Fracture Non-Union. Cochrane Database of Systematic Reviews, No. 1, Article No. CD004712. http://dx.doi.org/10.1002/14651858.cd004712.pub2

[13] Ueng, S.W., Lee, S.S., Lin, S.S., Wang, C.R., Liu, S.J., Tai, C.L. and Shih, C.H. (1999) Hyperbaric Oxygen Therapy Mitigates the Adverse Effect of Cigarette Smoking on the Bone Healing of Tibial Lengthening: An Experimental Study on Rabbits. The Journal of Trauma, 47, 752-759. http://dx.doi.org/10.1097/00005373-199910000-00023

[14] Urayama, H., Takemura, H., Kasajima, F., Tsuchida, K., Katada, S. and Watanabe, Y. (1992) Hyperbaric Oxygenation Therapy for Chronic Occlusive Arterial Diseases of the Extremities. Nihon Geka Gakkai Zasshi, 93, 429-433.

[15] Ang, E., Black, C., Irish, J., Brown, D.H., Gullane, P., O’Sullivan, B. and Neligan, P.C. (2003) Reconstructive Options in the Treatment of Osteoradionecrosis of the Craniomaxillofacial Skeleton. British Journal of Plastic Surgery, 56, 92-99. http://dx.doi.org/10.1016/S0007-1226(03)00085-7

[16] Braune, C., Hamm, J., Bohmer, D., Scale, D. and Zichner, L. (2002) Hyperbaric Oxygenation as a Successful Therapeutic Approach in Oral Wound Dehiscence after Operative Stabilization of an Unstable Post-Traumatic Odontoid Non-Union. Archives of Orthopaedic and Trauma Surgery, 122, 115-119. http://dx.doi.org/10.1007/s004020100329

[17] Ueng, S.W., Lee, S.S., Lin, S.S., Wang, C.R., Liu, S.J., Yang, H.F., Tai, C.L. and Shih, C.H. (1998) Bone Healing of Tibial Lengthening Is Enhanced by Hyperbaric Oxygen Therapy: A Study of Bone Mineral Density and Torsional Strength on Rabbits. The Journal of Trauma, 44, 676-681. http://dx.doi.org/10.1097/00005373-199804000-00020

[18] Annane, D., Depondt, J., Aubert, P., Villart, M., Gehanno, P., Gajdos, P. and Chevret, S. (2004) Hyperbaric Oxygen Therapy for Radionecrosis of the Jaw: A Randomized, Placebo-Controlled, Double-Blind Trial from the ORN96 Study Group. Journal of Clinical Oncology, 22, 4893-4900. http://dx.doi.org/10.1200/jco.2004.09.006

[19] Laden, G. (2005) Hyperbaric Oxygen Therapy for Radionecrosis: Clear Advice from Confusing Data. Journal of Clinical Oncology, 23, 4465-4468. http://dx.doi.org/10.1200/jco.2004.00.9829

[20] Vaananen, H.K. and Laitala-Leinonen, T. (2008) Osteoclast Lineage and Function. Archives of Biochemistry and Biophysics, 473, 132-138. http://dx.doi.org/10.1016/j.abb.2008.03.037

[21] Rousselle, A.V. and Heymann, D. (2002) Osteoclastic Acidification Pathways during Bone Resorption. Bone, 30, 533- 
540. http://dx.doi.org/10.1016/S8756-3282(02)00672-5

[22] Wong, B.R., Rho, J., Arron, J., Robinson, E., Orlinick, J., Chao, M., Kalachikov, S., Cayani, E., Bartlett III, F.S., Frankel, W.N., Lee, S.Y. and Choi, Y. (1997) TRANCE Is a Novel Ligand of the Tumor Necrosis Factor Receptor Family That Activates C-Jun N-Terminal Kinase in T Cells. The Journal of Biological Chemistry, 272, 25190-25194. http://dx.doi.org/10.1074/jbc.272.40.25190

[23] Yasuda, H., Shima, N., Nakagawa, N., Yamaguchi, K., Kinosaki, M., Mochizuki, S., Tomoyasu, A., Yano, K., Goto, M., Murakami, A., Tsuda, E., Morinaga, T., Higashio, K., Udagawa, N., Takahashi, N. and Suda, T. (1998) Osteoclast Differentiation Factor Is a Ligand for Osteoprotegerin/Osteoclastogenesis-Inhibitory Factor and Is Identical to TRANCE/RANKL. Proceedings of the National Academy of Sciences of the United States of America, 95, 3597-3602. http://dx.doi.org/10.1073/pnas.95.7.3597

[24] Lacey, D.L., Timms, E., Tan, H.L., Kelley, M.J., Dunstan, C.R., Burgess, T., Elliott, R., Colombero, A., Elliott, G., Scully, S., Hsu, H., Sullivan, J., Hawkins, N., Davy, E., Capparelli, C., Eli, A., Qian, Y.X., Kaufman, S., Sarosi, I., Shalhoub, V., Senaldi, G., Guo, J., Delaney, J. and Boyle, W.J. (1998) Osteoprotegerin Ligand Is a Cytokine That Regulates Osteoclast Differentiation and Activation. Cell, 93, 165-176. http://dx.doi.org/10.1016/S0092-8674(00)81569-X

[25] Galibert, L., Tometsko, M.E., Anderson, D.M., Cosman, D. and Dougall, W.C. (1998) The Involvement of Multiple Tumor Necrosis Factor Receptor (TNFR)-Associated Factors in the Signaling Mechanisms of Receptor Activator of NF-KappaB, a Member of the TNFR Superfamily. The Journal of Biological Chemistry, 273, 34120-34127. http://dx.doi.org/10.1074/jbc.273.51.34120

[26] Takayanagi, H., Kim, S., Koga, T., Nishina, H., Isshiki, M., Yoshida, H., Saiura, A., lsobe, M., Yokochi, T., Inoue, J., Wagner, E.F., Mak, T.W., Kodama, T. and Taniguchi, T. (2002) Induction and Activation of the Transcription Factor NFATc1 (NFAT2) Integrate RANKL Signaling in Terminal Differentiation of Osteoclasts. Developmental Cell, 3 , 889-901. http://dx.doi.org/10.1016/S1534-5807(02)00369-6

[27] Takayanagi, H.N. (2007) Osteoimmunology: Shared Mechanisms and Crosstalk between the Immune and Bone Systems. Nature Reviews Immunology, 7, 292-304.

[28] Asagiri, M., et al. (2005) Autoamplification of NFATc1 Expression Determines Its Essential Role in Bone Homeostasis. The Journal of Experimental Medicine, 202, 1261-1269. http://dx.doi.org/10.1084/jem.20051150

[29] Czupalla, C., Mansukoski, H., Pursche, T., et al. (2005) Comparative Study of Protein and mRNA Expression during Osteoclastogenesis. Proteomics, 5, 3868-3875. http://dx.doi.org/10.1002/pmic.200402059

[30] Li, X., Qin, L., Bergenstock, M., et al. (2007) Parathyroid Hormone Stimulates Osteoblastic Expression of MCP-1 to Recruit and Increase the Fusion of Pre/Osteoclasts. The Journal of Biological Chemistry, 282, 33098-33106. http://dx.doi.org/10.1074/jbc.m611781200

[31] Mozar, A., Haren, N., Chausseraud, M., et al. (2008) High Extracellular Inorganic Phosphate Oncentration Inhibits RANK-RANKL Signaling in Osteoclast-Like Cells. Journal of Cellular Physiology, 215, 47-54. http://dx.doi.org/10.1002/jcp.21283

[32] Hsu, H., Lacey, D., Dunstan, C., et al. (1999) Tumor Necrosis Factor Receptor Family Member RANKL Mediates Osteoclast Differentiation and Activation Induced by Osteoprotegerin Ligand. Proceedings of the National Academy of Sciences of the United States of America, 96, 3540-3545. http://dx.doi.org/10.1073/pnas.96.7.3540

[33] Lossdörfer, S., Götz, W. and Jäger, A. (2011) PTH(1-34)-Induced Changes in RANKL and OPG Expression by Human PDL Cells Modify Osteoclast Biology in a Co-Culture Model with RAW 264.7 Cells. Clinical Oral Investigations, 15, 941-952.

[34] Lu, H.K., Chen, Y.L., Chang, H.C., et al. (2006) Identification of the Osteoprotegerin/Receptor Activator of Nuclear Factor-Kappa B Ligand System in Gingival Crevicular Fluid and Tissue of Patients with Chronic Periodontitis. Journal of Periodontal Research, 41, 354-360. http://dx.doi.org/10.1111/j.1600-0765.2006.00883.x

[35] Koga, K., Takaesu, G., Yoshida, R., Nakaya, M., Kobayahi, T., Kinjyo, I. and Yoshimura, A. (2009) Cyclic Adenosine Monophosphate Suppresses the Transcription of Proinflammatory Cytokines via the Phosphorylated C-Fos Protein. Cell Press Immunity, 30, 372-383.

[36] Oka, S., Kubota, Y., Yamashiro, T., Ogata, S., Ninomiya, T., Ito, S. and Shirasuna, K. (2005) Effects of Positive Pressure in Odontogenic Keratocysts. Journal of Dental Research, 84, 913-918. http://dx.doi.org/10.1177/154405910508401008

[37] Kang, T.S., Gorti, G.K., Quan, S.Y., Ho, M. and Koch, R.J. (2004) Effect of Hyperbaric Oxygen on the Growth Factor Profile of Fibroblasts. JAMA Facial Plastic Surgery, 6, 31-35. http://dx.doi.org/10.1001/archfaci.6.1.31

[38] Conconi, M.T., Baiguera, S., Guidolin, D., Furlan, C., Menti, A.M., Vigolo, S., Belloni, A.S., Parnigotto, P.P. and Nussdorfer, G.G. (2003) Effects of Hyperbaric Oxygen on Proliferative and Apoptotic Activities and Reactive Oxygen Species Generation in Mouse Fibroblast 3T3/J2 Cell Line. Journal of Investigative Medicine, 51, 227-232. 
http://dx.doi.org/10.1097/00042871-200307000-00024

[39] Mizuguchi, T., Oshima, H., Imaizumi, H., Kohara, H., Kawamoto, M., Nobuoka, T., Kawasaki, H., Harada, K., Masuda, Y., Kikkawa, Y., Mitaka, T., Asai, Y. and Hirata, K. (2005) Hyperbaric Oxygen Stimulates Cell Proliferation and Normalizes Multidrug Resistance Protein-2 Protein Localization in Primary Rat Hepatocytes. Wound Repair Regeneration, 13, 551-557.

[40] Granowitz, E.V., Tonomura, N., Benson, R.M., Katz, D.M., Band, V., Makari-Judson, G.P. and Osborne, B.A. (2005) Hyperbaric Oxygen Inhibits Benign and Malignant Human Mammary Epithelial Cell Proliferation. Anticancer Research, 25, 3833-3842.

[41] Okubo, Y., Bessho, K., Fujimura, K., Kusumoto, K., Ogawa, Y. and Iizuka, T. (2001) Effect of Hyperbaric Oxygenation on Bone Induced by Recombinant Human Bone Morphogenetic Protein-2. British Journal of Oral and Maxillofacial Surgery, 39, 91-95. http://dx.doi.org/10.1054/bjom.2000.0550

[42] Johnsson, A.A., Sawaii, T., Jacobsson, M., Granstrom, G. and Turesson, I. (1999) A Histomorphometric Study of Bone Reactions to Titanium Implants in Irradiated Bone and the Effect of Hyperbaric Oxygen Treatment. The International Journal of Oral \& Maxillofacial Implants, 14, 699-706.

[43] Kirkeby, O.J. (1991) Revascularization of Bone Grafts in Rats. The Journal of Bone \& Joint Surgery, 73, 501-505.

[44] Toribatake, Y., Hutton, W.C., Tomita, K. and Boden, S.D. (1998) Vascularization of the Fusion Mass in a Posterolateral Intertransverse Process Fusion. Spine, 23, 1149-1154. http://dx.doi.org/10.1097/00007632-199805150-00015

[45] Marx, R.E. (1983) A New Concept in the Treatment of Osteoradionecrosis. Journal of Oral and Maxillofacial Surgery, 41, 351-357. http://dx.doi.org/10.1016/S0278-2391(83)80005-6

[46] Marx, R.E. (1983) Osteoradionecrosis: A New Concept of Its Pathophysiology. Journal of Oral and Maxillofacial Surgery, 41, 283-288. http://dx.doi.org/10.1016/0278-2391(83)90294-X

[47] Elayan, I.M., Axley, M.J., Prasad, P.V., Ahlers, S.T. and Auker, C.R. (2000) Effect of Hyperbaric Oxygen Treatment on Nitric Oxide and Oxygen Free Radicals in Rat Brain. Journal of Neurophysiology, 83, 2022-2029.

[48] Tandara, A.A. and Mustoe, T.A. (2004) Oxygen in Wound Healing-More Than a Nutrient. World Journal of Surgery, 28, 294-300. http://dx.doi.org/10.1007/s00268-003-7400-2

[49] Boykin Jr, J.V. and Baylis, C. (2007) Hyperbaric Oxygen Therapy Mediates Increased Nitric Oxide Production Associated with Wound Hearing: A Preliminary Study. Advances in Skin \& Wound Care, 20, 382-389. http://dx.doi.org/10.1097/01.ASW.0000280198.81130.d5

[50] Thom, S.R., Bhopale, V.M., Velazquez, O.C., et al. (2006) Stem Cell Mobilization by Hyperbaric Oxygen. American Journal of Physiology: Heart and Circulatory Physiology, 290, H1378-H1386. http://dx.doi.org/10.1152/ajpheart.00888.2005

[51] Asano, T., Kaneko, E., Shinozaki, S., et al. (2007) Hyperbaric Oxygen Induces Basic Fibroblast Growth Factor and Hepatocyte Growth Factor Expression, and Enhances Blood Perfusion and Muscle Regeneration in Mouse Ischemic Hind Limbs. Circulation Journal, 71, 405-411. http://dx.doi.org/10.1253/circj.71.405

[52] Gallagher, K.A., Goldstein, L.J., Thom, S.R., et al. (2006) Hyperbaric Oxygen and Bone Marrow-Derived Endothelial Progenitor Cells in Diabetic Wound Healing. Vascular, 14, 328-337. http://dx.doi.org/10.2310/6670.2006.00057

[53] Gutsaeva, D.R., Suliman, H.B., Carraway, M.S., et al. (2006) Oxygen-Induced Mitochondrial Biogenesis in the Rat Hippocampus. Neuroscience, 137, 493-504. http://dx.doi.org/10.1016/j.neuroscience.2005.07.061

[54] Cabigas, B.P., Su, J., Hutchins, W., et al. (2006) Hyperoxic and Hyperbaric-Induced Cardioprotection: Role of Nitric Oxide Synthase 3. Cardiovascular Research, 72, 143-151. http://dx.doi.org/10.1016/j.cardiores.2006.06.031

[55] Yu, X.H., Yang, Y.J., Wang, X., et al. (2006) Effect of Hyperbaric Oxygenation on Neural Stem Cells and Myelin in Neonatal Rats with Hypoxic-Ischemic Brain Damage. Chinese Journal of Contemporary Pediatrics, 8, 33-37.

[56] Liu, Z.J. and Velazquez, O.C. (2008) Hyperoxia, Endothelial Progenitor Cell Mobilization, and Diabetic Wound Healing. Antioxidants \& Redox Signaling, 10, 1869-1882. http://dx.doi.org/10.1089/ars.2008.2121

[57] Fok, T.C., Jan, A., Peel, S.A., et al. (2008) Hyperbaric Oxygen Results in Increased Vascular Endothelial Growth Factor (VEGF) Protein Expression in Rabbit Calvarial Critical-Sized Defects. Oral Surgery, Oral Medicine, Oral Pathology, Oral Radiology, and Endodontology, 105, 417-422. http://dx.doi.org/10.1016/j.tripleo.2007.07.015

[58] Lee, C.C., Chen, S.C., Tsai, S.C., et al. (2006) Hyperbaric Oxygen Induces VEGF Expression through ERK, JNK and C-Jun/AP-1 Activation in Human Umbilical Vein Endothelial Cells. Journal of Biomedical Science, 13, 143-156. http://dx.doi.org/10.1007/s11373-005-9037-7

[59] Freiberger, J.J., Padilla-Burgos, R., Chhoeu, A.H., et al. (2007) Hyperbaric Oxygen Treatment and BisphosphonateInduced Osteonecrosis of the Jaw: A Case Series. Journal of Oral and Maxillofacial Surgery, 65, 1321-1327. http://dx.doi.org/10.1016/j.joms.2007.03.019 
[60] Peng, Z., Ren, P., Kang, Z., et al. (2008) Up-Regulated HIF-1Alpha Is Involved in the Hypoxic Tolerance Induced by Hyperbaric Oxygen Preconditioning. Brain Research, 1212, 71-78. http://dx.doi.org/10.1016/j.brainres.2008.03.027

[61] Li, Z., Liu, W., Kang, Z., et al. (2008) Mechanism of Hyperbaric Oxygen Preconditioning in Neonatal Hypoxia-Ischemia Rat Model. Brain Research, 1196, 151-156. http://dx.doi.org/10.1016/j.brainres.2007.12.039

[62] Yogaratnam, J.Z., Laden, G., Madden, L.A., et al. (2006) Hyperbaric Oxygen: A New Drug in Myocardial Revascularization and Protection? Cardiovascular Revascularization Medicine, 7, 146-154. http://dx.doi.org/10.1016/j.carrev.2006.04.006

[63] Allen, B.W., Demchenko, I.T. and Piantadosi, C.A. (2009) Two Faces of Nitric Oxide: Implications for Cellular Mechanisms of Oxygen Toxicity. Journal of Applied Physiology, 106, 662-667. http://dx.doi.org/10.1152/japplphysiol.91109.2008

[64] Van'T Hof, R.J. and Ralston, S.H. (2001) Nitric Oxide and Bone. Immunology, 103, 255-261. http://dx.doi.org/10.1046/j.1365-2567.2001.01261.x

[65] Bai, X.C., Lu, D., Liu, A.L., et al. (2005) Reactive Oxygen Species Stimulates Receptor Activator of NF-KappaB Ligand Expression in Osteoblast. The Journal of Biological Chemistry, 280, 17497-17506. http://dx.doi.org/10.1074/jbc.M409332200

[66] Khosla, S. (2001) Minireview: The OPG/RANKL/RANK System. Endocrinology, 142, 5050-5055. http://dx.doi.org/10.1210/endo.142.12.8536 